\title{
Spending Habits of Public School Teachers in Palayan City
}

\author{
Fhrizz S. De Jesus' ${ }^{1}$, Margie B. De Jesus ${ }^{2}$ \\ ${ }^{1}$ Nueva Ecija University of Science and Technology, Cabanatuan, Philippines \\ ${ }^{2}$ DepEd Nueva Ecija, Leonor M. Bautista National High School, General Tinio, Philippines \\ Email: fhrizzdejesus01@gmail.com,maggiebdj@gmail.com
}

How to cite this paper: De Jesus, F.S. and De Jesus, M.B. (2021) Spending Habits of Public School Teachers in Palayan City. Open Access Library Journal, 8: e6332. https://doi.org/10.4236/oalib.1106332

Received: April 17, 2020

Accepted: February 23, 2021

Published: February 26, 2021

Copyright $\odot 2021$ by author(s) and Open Access Library Inc.

This work is licensed under the Creative Commons Attribution International License (CC BY 4.0).

http://creativecommons.org/licenses/by/4.0/

\begin{abstract}
As the salary rise for teachers has been an on-going issue, the researchers studied the spending habits of the teaching personnel and their reasons in borrowing money from financing institutions. This study was conducted in twenty-two public schools in Palayan City with a total of one hundred seventy-seven teaching personnel as respondents. Descriptive research was used in this study through survey questionnaire and interview method in order to reveal the relationship between variables and to answer the research problems. From the result of the findings, it was concluded that teachers mostly spend on basic necessities and they seldom incur miscellaneous and leisure activities. The inflation rate was the most common problem teaching personnel encountered in the spending. The researchers formulated recommendation that may help the teachers in spending.
\end{abstract}

\section{Subject Areas}

Business and Economics, Education, Social Science

\section{Keywords}

Spending, Habits, Public School, Teachers

\section{Introduction}

In economic research, the idea of investment plays an important role as it promotes the stabilization of economic development. [1] Economists have long been interested in the factors determining how a society divides its income proportionally between consumption and saving. The relationship between expected income and consumption is one that has been explored by many economists. The person may sustain consumption and savings at their current rate, increase consumption and reduce current savings, or steadily increase consumption and reduce savings. Many people prefer one of the latter choices, before 
they have earned this income, spending money out of their potential income. It may also be viewed as the sum of money that is spent on something. Some people prefer to take their wallet with some card or money and spend it. Every day, we ultimately make decisions that can feel like well-considered decisionmaking, but they are not. They are habits or behaviors, each habit means nothing of its own and how we spend our money, especially when you have a job and make money for the future, has a significant effect on our wellbeing and has a responsibility to your families.

Public school teachers play an important role in our society, especially for the students. Teachers used classroom instructions and presentations to help the students learn and apply different concepts. In addition, public school teachers make their way clearly in the economic activities, in the spending portion, to create its part.

Many public school teachers devote their salaries or profits to the daily needs of themselves and their particular families because of inflation and an alarming rise in the cost of living today. It is their utmost priority to make sure that their basic necessities are supplied first before anything else [2]. As added, once these necessities are gained, then that is the time that other/miscellaneous expenses come in the picture.

As teachers, the researchers believed that conducting this study was necessary and critical, particularly for the researcher to discover and be prepared for their respective profession. The researchers also felt that the comparative conduct of saving and investing had multiple variables. The goal of the research is to investigate the spending patterns and the problems faced by the teaching personnel in Palayan City, Nueva Ecija. This study could also be used by the future researchers as a reference and may encourage them to work on the financial stewardship and could be used for the development of financial intervention.

\section{Conceptual Framework}

One of the essential skills that people must acquire to function in our society is the ability to deal with money [3].

The need to investigate financial behavior among teachers is important since teachers are among role model figures who can influence the young's generation's financial knowledge and skills in personal financial management success [4].

According to [2], the teachers always spend their salary in Basic necessity and they seldom incur Leisure and Miscellaneous.

This research will help the teaching personnel and the Government to further assess the spending habits of the public schools teachers and to identify their problems in their spending habits. The researchers believed that the findings of the study could provide relevant information and insights for the teaching personnel and the government.

\section{Objectives of the Study}

The study described the Spending Habit of the Public School Teachers in terms 
of their Basic Necessity, Leisure Activities, and Miscellaneous and to identify the problems encountered by the public teachers in their spending habits.

\section{Methodology}

The study used descriptive method to determine the spending habits of public school teachers in Palayan City.

The researchers use expert sampling which is a type of purposive sampling. Expert sampling is where you draw your sample from experts in the field you are studying. It is used to know the opinions or assessment of people with a high degree about the study area.

For this study, the researcher utilized 22 public schools with 177 samples out of 317 teaching population in Palayan City, both High schools and Elementary Schools. It was computed through Slovin's Formula with 95\% level of confidence. These participants were part of the work force of the Department of Education assigned in different public schools in Palayan City. The samples were also consumers who were spending their income for the daily needs of themselves and their particular families.

The research instrument used was survey method and interview, wherein respondents answered questions administered through questionnaires and interviews. The instrument used was patterned and modified from the work of Perculeza, et al. (2016) [2] entitled "Spending Behavior of the Teaching Personnel in an Asian University".

The instrument was formulated in the modified 4-point Likert-scale ranging from Always (4), through Sometimes (3), Seldom (2) to Never Subjects were then instructed to rate the statements and answer the question. Also, it comprises of the problems encountered by the public school teachers in their spending habits. This part was made up of an open-ended question. The respondents were asked to write their honest opinions regarding the questions being asked.

The reliability coefficient of the instrument was tested and measured with a score of 0.889 , which means that the instrument has a good internal consistency. The validity of the research instrument was established by presenting the developed research instrument for the comments of experts who all together rated the instrument with 4.64 weighted mean with a verbal interpretation of "very good".

The data collected from the locale were encoded, tallied and analyzed using the following statistical tools were used. Data presentation of the given scale was used to interpret the results of the information gathered.

To determine the respondents' degree of perception, the weighted mean was computed using the following formula: Weighted mean ( $\Sigma \mathrm{WM})$ is equal to total weighted frequency $(\Sigma \mathrm{WF})$ divided by the total number of cases $(\mathrm{F})$.

The percentage frequency distribution was computed using the formula: frequency (F) divided by the sample (N) and multiply by one hundred (100). The researchers used ranking to compare items to each other by placing them in order of preferences. 


\section{Results and Discussions}

Table 1 shows the spending habits for foods. Respondents always spend in necessary food as it obtained the highest mean of 3.78. Respondents always contributed in food allowance as shown in the mean of 3.44, ranked as the second. It also shows that they sometimes incur luxurious food as it obtained the lowest weighted mean of 2.52 .

It turned out that necessary food was the most basic needs of human. Foods are obvious fundamental needs to keep the body alive and to work properly. Without food people are ineffective and cannot develop further needs. That is why respondents prioritize in necessary food more than others.

Food is one of the basic necessities of humans, and it stands first among all basic needs-food, shelter, and clothing. It is important as it nourishes the human body-sustaining the very existences of humans [5].

Table 2 shows the spending habits for clothing. The respondents sometimes spend money to buy clothes for their family as it got the highest turn out with a 3.06 mean. Respondents buy clothes occasionally $(\mathrm{WM}=2.97)$ and spend money in unbranded clothes $(\mathrm{WM}=2.88)$ rather than branded clothes $(\mathrm{WM}=2.41)$.

Public teachers have simpler lives and necessary clothes are more priority than luxurious and excessive. It also shows that budget was allotted not only for teachers' own expenses but for the whole family. Since the respondents are teachers, according to the respondents, they buy necessary clothes because they wanted to be presentable to look as professionals.

The way you look says a lot about you [6]. Studies show inappropriate dressing or grooming causes 40 percent of job rejections. Dressing professionally can make you feel better about yourself.

Table 3 shows the spending habits for education. As seen on the table, the highest turnout was the school expenses with a weighted mean of 3.40, education as the top priority in budget got a 3.34 weighted mean, followed by children's education in public schools with 2.83 weighted mean, education for higher degree had 2.51 weighted mean and education of children from private school got the lowest turnout of 1.55 weighted mean interpreted as never.

Table 1. Assessment of spending habits according to basic necessity.

\begin{tabular}{|c|c|c|c|}
\hline Food & WM & VI & Ranking \\
\hline 1) I spend money for necessary food. & 3.78 & Always & 1 \\
\hline 2) I buy luxurious food. & 2.52 & Sometimes & 6 \\
\hline 3) My family and I eat in a restaurant or fast-food & 2.72 & Sometimes & 5 \\
\hline 4) My family and I took a snack a day. & 3.09 & Sometimes & 4 \\
\hline 5) My family and I contribute for our food budget. & 3.44 & Always & 2 \\
\hline 6) I provide the whole food allowance for our family. & 3.17 & Sometimes & 3 \\
\hline Average Weighted Mean & 3.12 & Sometimes & \\
\hline
\end{tabular}


Table 2. Basic necessity with regards to clothes.

\begin{tabular}{lccc}
\hline \multicolumn{1}{c}{ Clothes } & WM & VI & Ranking \\
\hline $\begin{array}{l}\text { 1) I spend money for branded clothes. } \\
\text { 2) I spend my own money to buy clothes for my family. }\end{array}$ & 3.41 & Seldom & 5 \\
$\begin{array}{l}\text { 3) I buy excessive clothes. } \\
\text { 4) I spend money for unbranded clothes. }\end{array}$ & 2.08 & Seldom & 7 \\
5) I buy clothes every month. & 2.88 & Sometimes & 3 \\
6) My family and I buy clothes occasionally. & 2.19 & Seldom & 6 \\
7) I provide the whole clothing allowance for our family. & 2.67 & Sometimes & 4 \\
8) Clothes are top priority in my budget. & 2.97 & Sometimes & 2 \\
Average Weighted Mean & 1.71 & Never & 8
\end{tabular}

Table 3. Basic necessity with regards to education.

\begin{tabular}{|c|c|c|c|}
\hline Education & WM & VI & Ranking \\
\hline 1) I sent my child/children to public school. & 2.83 & Sometimes & 3 \\
\hline 2) I sent my child/children to private school. & 1.55 & Never & 5 \\
\hline $\begin{array}{l}\text { 3) I am currently studying for higher education on my own } \\
\text { expense. }\end{array}$ & 2.51 & Sometimes & 4 \\
\hline $\begin{array}{l}\text { 4) I include school expenses (e.g. Supplies, uniform, etc.) in } \\
\text { my budget. }\end{array}$ & 3.40 & Always & 1 \\
\hline 5) Education is top priority in my budget. & 3.34 & Always & 2 \\
\hline Average Weighted Mean & 2.70 & Sometimes & \\
\hline
\end{tabular}

Education is essential for any kind of development to enlighten the individual and develop the capacity to the limit. According to the respondents, when it comes to education, teachers allocated more money for the children rather than their own. As added, they need to allocate different school expenses in their budget because they believed in the importance of education especially for the future of their children.

Budgeting for school expenses such as clothes, supplies and tuition is a no-brainer, but parents need to plan ahead for additional costs. Without properly planning for things like sports, music, pictures, teacher gifts, field trips, dances, fundraising events and other extracurricular activities, parents will find themselves struggling to come up with hundreds of dollars or more throughout the year [7].

Table 4 shows the spending habits for housing. Respondents never allocated money for house as shown on its composite mean 1.62. House renovation ob- 
tained 2.30 as the highest turnout, house rent (1.26) and house loan (1.32) was interpreted as never.

Teachers never have budget for housing as long as house was already constructed. The respondents said that house renovation was seldom done because they wanted to maximize the efficiency of their house space to provide them comfortability and to make the available spaces into a functional area.

Home renovation is important since it improves the style, comfort, enjoyment, and value of the home. [8] Home remodeling allows you to customize your home to your preferences and needs. It is an excellent opportunity to create a comfortable space and make it more useful and enjoyable.

Table 5 shows the spending habits for health. Respondents sometimes spend money in health insurance as it got the highest mean of 3.22, followed by the expenses for vitamins with 3.01 weighted mean, 2.58 weighted mean for monthly check-up and the lowest turnout was the monthly health maintenance with 2.38 weighted mean.

Respondents allocated more in health insurance because most people need medical care at some point. Health insurance covered this cost and offered many other important benefits. Respondents revealed that Health insurance provides protection from unexpected high medical costs. As added, the health insurance serves as an investment to cover up health issues and concerns occurred in the family.

It's important to have health insurance as a safety net [9]. If you unexpectedly get sick or injured, health insurance is there to help cover costs that you likely can't afford to pay on your own.

Table 4. Basic necessity with regards to house.

\begin{tabular}{lccc}
\hline \multicolumn{1}{c}{ House } & WM & VI & Ranking \\
\hline 1) I rent a house. & 1.26 & Never & 3 \\
2) I pay house loans. & 1.32 & Never & 2 \\
3) I get my house renovated. & 2.30 & Seldom & 1 \\
Average Weighted Mean & 1.62 & Never & \\
\hline
\end{tabular}

Table 5. Basic necessity with regards to health.

\begin{tabular}{lccc}
\hline \multicolumn{1}{c}{ Health } & WM & VI & Ranking \\
\hline $\begin{array}{l}\text { 1) I pay health insurance. } \\
\text { 2) I usually buy medicine for my health maintenance. }\end{array}$ & 2.22 & Sometimes & 1 \\
3) I buy vitamins as protection from illness. & 3.01 & Sometimes & 2 \\
4) I allocate budget for monthly check up. & 2.58 & Sometimes & 3 \\
Average Weighted Mean & 2.81 & Sometimes
\end{tabular}


Table 6 below shows the spending habits for other indicators. It obtained a composite mean of 3.22 interpreted as sometimes. The highest turnout was electric bill ( $\mathrm{WM}=3.63$ ) followed by water bill ( $\mathrm{WM}=3.51)$. It also shows that they sometimes allotted money for load $(\mathrm{WM}=3.13)$ and pay for internet connection (WM = 2.61).

Bills to pay had the highest composite mean because the bills listed above is used for daily survival. These bills are necessary part of our daily living which makes the life comfortable. According to respondents, electricity is one of the important utilities in their daily lives. As added, without electricity it will be uncomfortable for them to move and accomplish household chores and office work.

Electricity has many uses in our day to day life [10]. It is used for lighting rooms, working fans and domestic appliances like using electric stoves, $\mathrm{A} / \mathrm{C}$ and more. All these provide comfort to people.

Table 7 shows the spending habits for travel and outing. Travel and outing shows a composite mean of 2.06 (seldom). The highest contributor was travel out of town with a weighted mean of 2.58 , followed by recreational activities with a weighted mean of 2.40 and travel abroad was the lowest contributor with 1.30 interpreted as never.

Table 6. Basic necessity with regards to other indicators.

\begin{tabular}{lccc}
\hline \multicolumn{1}{c}{ Other Indicators } & WM & VI & Ranking \\
\hline $\begin{array}{l}\text { 1) I pay for my internet connection. } \\
\text { 2) I pay electric bills. }\end{array}$ & 2.61 & Sometimes & 4 \\
3) I pay for water bills. & 3.63 & Always & 1 \\
4) I allot load allowance in my budget. & 3.51 & Always & 3 \\
Average Weighted Mean & 3.13 & Sometimes & \\
\hline
\end{tabular}

Table 7. Leisure activities with regards to travel and outing.

\begin{tabular}{lccc}
\hline \multicolumn{1}{c}{ Travel \& Outing } & WM & VI & Ranking \\
\hline $\begin{array}{l}\text { 1) I travel abroad. } \\
\text { 2) I go out of town. }\end{array}$ & 1.30 & Never & 1 \\
3) I spend money for recreational activities. & 2.58 & Sometimes & 2 \\
4) Travelling is top priority in my budget. & 1.68 & Seldom & 4 \\
5) I go out with my family and pay for the expenses. & 2.34 & Seldom \\
Average Weighted Mean & & 2.06 & Seldom \\
\hline
\end{tabular}


The findings show teachers seldom travel. They sometimes go out of town but for the teachers' fellowship, educational tours, professional development for teachers, etc. This is due to the loads in the schedule such as creating of reports and forms needed to be accomplished. According to the respondents, though they like to save money, unplanned travel always occur which became an important errand for them. More so, though it's unavoidable, it's one of their most mismanaged expenses in their budget.

Based from Chavaia [11], travel either planned or unplanned, occurs all the time-whether it's to attend a friend's destination wedding, tackle your bucket list, network for business, or a vacation. This became part of the mismanaged expenses in the budget of the teachers.

Table 8 shows the spending habits for entertainment as it got a composite mean of 1.79. The entertainment through movie houses was ranked as 1 with 2.31 mean, followed by amusement parks with 2.13 and the lowest contributor was comedy bar with 1.48 weighted mean. Respondents seldom spent money in leisure activities as seen in the table.

Movie houses were place for some teachers to be entertained and to spend their free time. But, it seldom happened due to the lessons to prepare and some other requirements needed to comply. In this light, according to the respondents, this kind of leisure activity is not their priority which help them to control their spending over their budget.

Budgeting can help you gain a feeling of control over your money [12]. It allows you to prioritize your spending, track how you are doing, and realize when you need to stop.

Table 9 tackles those spending habits allotted on the miscellaneous factors. It shows that respondents seldom spend their money in the above factors as shown in the composite mean 2.42. Transportation became the biggest factor on which the respondents allocated their income, followed by loans to pay $(\mathrm{WM}=2.78)$ and gadgets $(\mathrm{WM}=2.21)$.

This means that teachers incurred such transportation expense for the reason that they needed to travel. Miscellaneous as the budget category that seemed to grow at will and, unless it is held in check with disciplined spending, it can consume a lot of money. As mentioned above, respondents seldom spend in miscellaneous because they know how to control miscellaneous in most effective ways.

You may agree the miscellaneous budget category can be one of the most challenging categories to manage and can turn your budget upside down if not carefully managed [13]. People often forget about miscellaneous spending or fail to communicate about it. It's also hard to identify all the expenses that should be associated to this category because it is obtained from the daily transactions.

Table 10 presents the summary of mean ratings of spending habits of public school teachers. Based on the weighted mean, the Basic Necessity got the highest score of 2.67 with the interpretation, Sometimes, while the Leisure Activities got the lowest score of 1.93 with verbal interpretation of Seldom. 
Table 8. Leisure activities with regards to entertainment.

\begin{tabular}{lccc}
\hline \multicolumn{1}{c}{ Entertainment } & WM & VI & Ranking \\
\hline 1) I go to movie houses. & 2.31 & Seldom & 1 \\
2) I go to spa and other lifestyle center. & 1.85 & Seldom & 3 \\
3) I go to amusement parks. & 2.13 & Seldom & 2 \\
4) I go to Comedy, karaoke \& Disco bar. & 1.48 & Never & 5 \\
5) I go to Gaming club. & 1.52 & Never & 4 \\
Composite Mean & 1.79 & Seldom & \\
\hline
\end{tabular}

Table 9. Assessment of spending habits according to miscellaneous.

\begin{tabular}{lccc}
\hline \multicolumn{1}{c}{ Indicators } & WM & VI & Ranking \\
\hline \multicolumn{1}{c}{ Transportation } & & & \\
1) I buy fuels for my vehicle. & 3.12 & Sometimes & 1 \\
2) I use to commute. & 2.97 & Sometimes & 2 \\
Average Weighted Mean & 3.06 & Sometimes &
\end{tabular}

\section{Gadgets}

\begin{tabular}{llll} 
I buy gadgets. & 2.21 & Seldom & 4 \\
\hline \multicolumn{1}{c}{ Jewelry } & & \\
Loan & 1.83 & Seldom & 5 \\
\hline $\begin{array}{l}\text { I buy jewelry. } \\
\text { I pay other type of loan. }\end{array}$ & 2.78 & Sometimes & 3 \\
\hline \multicolumn{2}{c}{ Charity \& Foundation } & & \\
I spend money for donations. & & & \\
\hline
\end{tabular}

Table 10. Summary of spending habits.

\begin{tabular}{lccc}
\hline \multicolumn{1}{c}{ Spending Habits Indicators } & WM & VI & Ranking \\
\hline 1) Basic Necessity & 2.67 & Sometimes & 1 \\
2) Leisure Activities & 1.93 & Seldom & 3 \\
3) Miscellaneous & 2.42 & Seldom & 2 \\
Composite Mean & 2.34 & Seldom & \\
\hline
\end{tabular}


The findings point out that the priority of the respondents are their basic needs. According to the respondents, before anything else, they should first satisfy their basic needs before satisfying their wants. More so, great control in buying unnecessary things should be done to fit with their budget and income.

Physiological needs are the lowest level of Maslow's changed of needs [14]. They are the most indispensable things a person needs to survive. If someone is lacking in more than one need, they're likely to try to meet these physiological needs first.

Table 11 shows the problems encountered in spending habits. The assessment of the problems was interpreted with a composite mean of 1.92. The items were ranked and the top 3 problems encountered were inflation rate with a weighted mean of 2.90 , overspending with a 2.19 weighted mean and misallocation of money with 2.12 .

Inflation means people need to pay more for the goods and services. It could also mean as the reduction of the value of money, as consumers are able to purchase less than before. As the inflation rises, the value of the peso diminishes more quickly. Respondents revealed that inflation nowadays was part of the living which cannot be removed. As added, the respondents stated that we should adopt with the inflation movement for us to spend our income efficiently. On the other hand, indebtedness will follow if the income will not manage well.

Inflation still affects your cost of living by increasing the cost of goods and services [15]. People who have a high standard of living but not a high enough income end up borrowing money to make up the difference. When inflation rises, borrowing money becomes very expensive. This means either people take out fewer loans or they're unable to spend less money because it's going towards debt payments.

Table 11. The problems encountered by the teachers in their spending habits.

\begin{tabular}{|c|c|c|c|}
\hline Indicators & WM & VI & Ranking \\
\hline 1) I misallocate my Money. & 2.12 & Seldom & 3 \\
\hline 2) I overspend. & 2.19 & Seldom & 2 \\
\hline 3) I use credit cards to pay expenses. & 1.56 & Never & 7 \\
\hline 4) I am affected by inflation. & 2.90 & Sometimes & 1 \\
\hline 5) I am in deep debt. & 1.60 & Never & 6 \\
\hline 6) Financial stress leads to family misunderstanding. & 1.22 & Never & 8 \\
\hline 7) I have many dependents. & 1.77 & Seldom & 5 \\
\hline 8) I am the only bread winner of our family. & 2.03 & Seldom & 4 \\
\hline Composite Mean & 1.92 & Seldom & \\
\hline
\end{tabular}




\section{Conclusions}

The researchers recommend that in terms of Basic Necessity, the area for improvement was the spending regarding their houses. In terms of Leisure activities, the area for improvement for spending habits is entertainment. In terms of miscellaneous, the area for improvement is buying jewelry. For the problems encountered, the area for improvement is the financial stress that leads to family misunderstanding.

In light of the foregoing results, the researchers concluded that the spending habits of the public school teachers were spent for their basic necessities. On the contrary, the researchers suggest that the respondents improve their spending habits for their leisure activities to use their money effectively and efficiently. Also, it was recommended by the researchers to improve the financial management of the respondents so that it may not lead to family misunderstanding.

\section{Conflicts of Interests}

The authors declare no conflict of interest regarding the publication of this paper.

\section{References}

[1] CENGAGE (2015) Consumption Function. https://www.encyclopedia.com/history/united-states-and-canada/us-history/consu mption-economics\#A

[2] Perculeza, N.P., Andal, Y.P., Divino, M.A., Maderazo, C.J., Samonteza, Z. and Manongsong, J.L. (2016) Spending Behavior of the Teaching Personnel in an Asian University. Asia Pacific Journal of Multidisciplinary Research, 4, 99-108.

[3] Cummins, M.M., Jenkins, S.J. and Haskell, J.H. (2009) Financial Attitudes and Spending Habits of University Freshmen. Journal of Economics and Economic Education Research, 10.

https://www.abacademies.org/articles/jeeervol10no12009.pdf

[4] Zaimah, R., Sarmila, M.S., Lyndon, N., Azima, A.M., Selvadurai, S., Saad, S. and Er, A.C. (2013) Financial Behaviors of Female Teachers in Malaysia. Asian Social Science, 9. http://dx.doi.org/10.5539/ass.v9n8p34

[5] Joshi, S. (2019) Food-More than an Essential Need. https://nutritionmeetsfoodscience.com/2019/01/03/food-more-than-an-essential-ne ed

[6] Showalter, S.K. (2019) The Importance of Dressing Professionally. https://careertrend.com/facts-5136548-importance-dressing-professionally.html

[7] Woroch, A. (2018) 7 Ways to Manage Unexpected School Expenses. https://money.usnews.com/money/personal-finance/saving-and-budgeting/articles/ 2018-09-27/7-ways-to-manage-unexpected-school-expenses

[8] Beninato, S. (2019) What Are the Advantages of Home Renovation? https://www.renowow.ca/advantages-of-home-renovation

[9] Virginia Premier (2019) What Is Health Insurance and Why It Is Important? https://www.virginiapremier.com/what-is-health-insurance-and-why-is-it-importa $\underline{\mathrm{nt}}$ 
[10] Lekshmi, S. (2017) Importance of Electricity.

https://www.thehindu.com/features/kids/Importance-of-electricity/article16544961. ece

[11] Chavia, Q. (2015) Miscellaneous Travel Expenses.

http://www.wisebread.com/7-budget-items-you-may-be-forgetting

[12] Caldwell, M. (2020) Reason Why you should Budget Your Money? https://www.thebalance.com/reasons-to-budget-money-2385699

[13] Price, J. (2011) Managing the Miscellaneous Budget Category. https://www.biblemoneymatters.com/managing-the-miscellaneous-budget-category I

[14] CFI (2015) Maslow's Hierachy of Needs. https://corporatefinanceinstitute.com/resources/knowledge/other/maslows-hierarch y-of-needs/\#: :text=\%231\%3A\%20Physiological\%20Needs,from\%20their\%20instin ct\%20to\%20survive

[15] Ranallo, J. (2018) How Does Inflation Affect Your Lifestyle? https://www.vectorwealth.com/blog/2019/5/9/how-does-inflation-affect-your-lifesty $\underline{\text { le }}$ 